\title{
O MINISTÉRIO PÚBLICO NA JUSTIÇA CONSENSUAL DO ACORDO DE NÃO PERSECUÇÃO PENAL
}

\section{THE PUBLIC MINISTRY IN CONSENSUS JUSTICE OF THE CRIMINAL NON-PERSECUTION AGREEMENT}

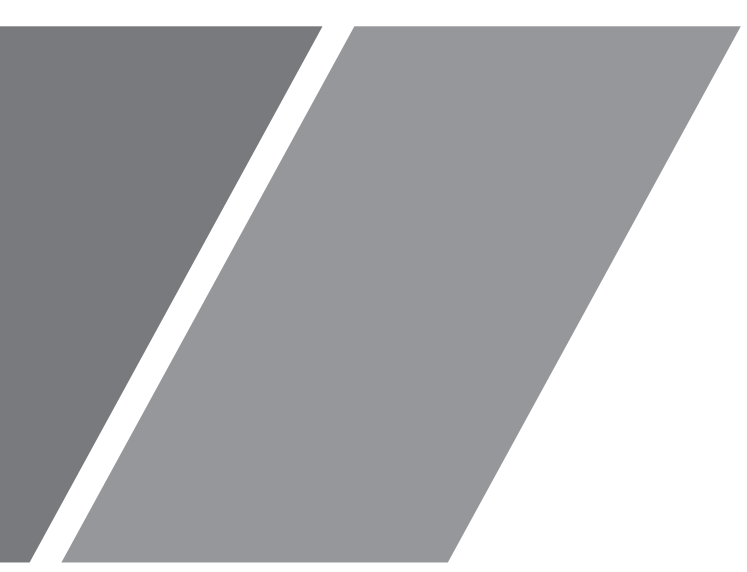




\title{
O MINISTÉRIO PÚBLICO NA JUSTIÇA CONSENSUAL DO ACORDO DE NÃO PERSECUÇÃO PENAL ${ }^{1}$
}

\author{
THE PUBLIC MINISTRY IN CONSENSUS JUSTICE OF THE CRIMINAL \\ NON-PERSECUTION AGREEMENT
}

Isabel Christina Prazeres Rodrigues ${ }^{2}$

\section{RESUMO}

A presente pesquisa aborda a matéria da justiça consensual como meio instrumental para conferir celeridade e eficiência ao ordenamento jurídico na seara penal e processual penal. Nesse sentido, busca-se estabelecer um estudo sobre a origem e a finalidade do Acordo de Não Persecução Penal - ANPP, firmado entre o Ministério Público e o autor da infração penal, a fim de alcançar uma justiça consensual por meio da aplicação de medidas não privativas de liberdade, bem como visa verificar o campo de atuação do órgão ministerial, diante da análise da legislação e do caso concreto, para viabilizar a tratativa de não denunciação.

Palavras-chave: Justiça consensual. Acordo de não persecução penal. Ministério Público.

\section{INTRODUÇÃO}

A Constituição Federal de 1988 conferiu nova roupagem ao ordenamento jurídico, fazendo com que as estruturas estatais se voltassem para os princípios de transformação social e proteção do bem comum. Nessa senda, o Constituinte estabeleceu uma forma diferenciada de atuação do Ministério Público, incumbindo-o da promoção de interesses estratégicos da sociedade, notadamente ressaltando a ele a titularidade privativa da ação penal pública, bem como lhe conferindo o exercício em defesa da ordem jurídica, do regime democrático e de interesses difusos, coletivos e individuais homogêneos.

Além disso, o Ministério Público passou a não mais se preocupar exclusivamente

1 Data de recebimento: 08/10/2020. Data de Aceite: 23/11/2020.

2 Bacharela em Direito, Pós-Graduada em Direito Penal e Processual Penal, Servidora do Ministério Público do Estado de Sergipe. E-mail: isabel.prazeres@hotmail.com. Currículo Lattes: http://lattes.cnpq.br/6680942336732335. ORCID: https://orcid.org/0000-0002-7472-359X. 
em interpor demandas perante o judiciário, mas ao contrário, visando a compreensão eficiente e transformadora de sua atuação, passou a adotar uma postura resolutiva dentro da própria instituição, deixando a judicialização para o último caso.

Essa nova forma de atuar do Parquet acompanhou as mudanças no âmbito do Direito Penal, especialmente com a flexibilização no princípio da obrigatoriedade da ação penal, que por critérios de política criminal e de utilidade social permite a aplicação de medidas não privativas de liberdade antes do oferecimento da denúncia para alcançar a justiça restaurativa e evitar o cárcere do autor do fato criminoso. Como exemplo disso, o ordenamento apresenta o instituto da transação penal, acordo de leniência, e, entre outros, o Acordo de Não Persecução Penal - ANPP, sendo esse último o objeto da presente pesquisa.

\section{AÇÃO PENAL PÚBLICA E O PRINCíPIO DA OBRIGATORIEDADE DA AÇÃO PENAL}

Com a prática de uma infração penal surge o interesse estatal de persecução penal, que, em regra, começa na fase inquisitorial do inquérito policial, com o escopo de colher elementos de autoria e materialidade para o oferecimento da denúncia, e termina com a aplicação da lei penal ao fato típico, ilícito e ao agente culpável.

De acordo com Renato Brasileiro (2014, pág. 185), "ação penal é o direito público subjetivo de pedir ao Estado-Juiz a aplicação do direito penal objetivo a um caso concreto". Ademais, com a aplicação da lei, o Estado pretende alcançar as finalidades da pena, que, pelos termos do artigo 59, caput, do Código Penal, será estabelecida "conforme necessário e suficiente para reprovação e prevenção do crime".

Como a pena deve, simultaneamente, evitar a prática de novas infrações e ser dirigida à pessoa do condenado - visando ao controle da violência e servir de contra estímulo ao crime, bem como evitar a reincidência e promover a ressocialização do infrator - o Direito Penal Brasileiro adotou a teoria mista ou unificadora, com dupla finalidade: retribuir e prevenir.

Nessa trilha, a doutrina, atualmente, aponta a necessidade de se observar não só a função social da pena, que busca atender os anseios do estado e da sociedade, mas também, mister é observar os fundamentos daquela, sendo estes: retribuição, reparação, denúncia, incapacitação, reabilitação e dissuasão.

Em apertada síntese, podemos dizer que a retribuição consiste em aplicar uma pena proporcional e correspondente à infração penal; que reparação é recompor a vítima por meio da reparação do dano causado pelo delito; que denúncia é a reprovação social propriamente dita; que incapacitação é a privação da liberdade do condenado, retirando-o 
do convívio social; que reabilitação é a recuperação educativa, de reinserção social; e que dissuasão é convencer o infrator de que o delito é tarefa desvantajosa e inadequada.

Ocorre que, com a crise do sistema penal brasileiro, que foi declarada em Estado de Coisa Inconstitucional ${ }^{3}$, a pena aplicada ao condenado acaba sendo transformada, unicamente, em castigo, retribuição, notadamente por ser o cárcere um ambiente de extrema violação de direitos, que afasta a dignidade da pessoa humana e é ineficiente nos fundamentos da sanção, especialmente sob o enfoque da ressocialização.

Com isso, surge a necessidade de que o ordenamento jurídico passe a buscar uma nova reflexão político-criminal para se alcançar resultados satisfatórios na dupla finalidade para alcançar tal objetivo, o direito penal começou a apresentar sérias mudanças, entre elas uma flexibilização no princípio da obrigatoriedade do direito penal.

De acordo com o princípio da obrigatoriedade da ação penal pública, também conhecido como princípio da legalidade processual, ao órgão ministerial não cabe a decisão sobre a possiblidade ou não de oferecer denúncia diante de elementos sérios e fundados da autoria e materialidade de um fato típico, ilícito e culpável.

Esse princípio confere um dever de atuação ao órgão persecutório criminal para denunciar o agente delituoso, não restando disponibilidade em seu dever de acusar, salvo as estritas hipóteses de arquivamento, ou na necessidade de outras diligências imprescindíveis para o oferecimento da inicial acusatória. Não obstante, tal obrigatoriedade deixou de ser absoluta, prevendo a lei institutos de mitigação ao referido princípio, vejamos.

Entre as exceções, há os institutos da composição civil e da transação penal, aplicados nos casos de infrações de menor potencial ofensivo, sendo regulados pela Lei $\mathrm{n}^{\circ}$ 9.099/1995.

Na composição dos danos civis, há um acordo entre o autor do fato e a vítima, essencialmente visando à reparação do dano, nos casos de ação penal privada e ação pública condicionada. Já na hipótese de transação penal, valendo-se do princípio da discricionariedade regrada ou mitigada, o Parquet, ao invés de oferecer denúncia, e desde que o autor do fato preencha os requisitos objetivos e subjetivos, pode propor a este a aplicação imediata de penas restritivas de direito ou multa.

3 Termo relativo à Arguição de Descumprimento de Preceito Fundamental 347 - Distrito Federal (STF, 2015). Nela, o
Partido Socialismo e Liberdade - PSOL buscou, por meio de arguição de descumprimento de preceito fundamental, com
pedido de medida liminar, o reconhecimento da figura do "estado de coisas inconstitucional" relativamente ao sistema
penitenciário brasileiro e a adoção de providências estruturais em face de lesões a preceitos fundamentais dos presos. As-
severou que a superlotação e as condições degradantes do sistema prisional configuram cenário fático incompatível com a
Constituição Federal, presente a ofensa de diversos preceitos fundamentais consideradas a dignidade da pessoa humana, a
vedação de tortura e de tratamento desumano, o direito de acesso à Justiça e os direitos sociais à saúde, educação, trabalho
e segurança dos presos. Sustentou também que o quadro resulta de uma multiplicidade de atos comissivos e omissivos dos
Poderes Públicos da União, dos Estados e do Distrito Federal, incluídos os de natureza normativa, administrativa e judicial. 
Também merece destaque o acordo de leniência disciplinado pela Lei n ${ }^{\circ}$ 12.529/2011, que dispõe sobre o Sistema Brasileiro de Defesa da Concorrência. Nesse diploma, a celebração do referido acordo, com os autores de crimes contra a ordem econômica e relacionados à prática de cartel, permite a suspensão do prazo prescricional e impede o oferecimento de denúncia em relação ao beneficiário, desde que este atenda às condições previstas no artigo 86 da Lei supracitada.

Outrossim, vale destacar o instituto da colaboração premiada declinada na Lei de organizações criminosas - Lei $\mathrm{n}^{\circ} 12.850 / 2013$, que prevê a possibilidade de o Ministério Público deixar de oferecer denúncia, se a proposta de acordo de colaboração referir-se a infração de cuja existência não tenha prévio conhecimento, mas desde que o colaborador não seja líder da organização e seja o primeiro a prestar efetiva colaboração à resolução do crime.

Podemos perceber que as exceções citadas podem conduzir a vários resultados, seja alcançando o caminho da justiça resolutiva, que encurta a fase de instrução criminal e aplica medidas não privativas de liberdade - como no caso da transação penal -, seja alcançando a espécie de direito penal premial, que permite ao autor do fato confessar e colaborar com as investigações e, em troca, receber benefícios, como não ter contra si uma ação penal iniciada.

\section{JUSTIÇA RESTAURATIVA NO PLANO EXTRAJUDICIAL}

A origem do direito penal foi pautada pela unilateralidade da reprovação, mas evoluiu para o conjunto repressão e prevenção. Já de forma contemporânea, a ciência criminal estabeleceu a subsidiariedade das penas privativas de liberdade, promovendo um direito penal mais humanista, visando, inclusive, à diminuição da população carcerária.

Entre as bases fundamentalistas da política do não encarceramento, encontram-se as Regras de Tóquio, formuladas para a prevenção do delito e tratamento do delinquente, cujo projeto foi aprovado no ano de 1990, pela Assembleia Geral das Nações Unidas, integrando a Resolução $n^{\circ} 45 / 110$, sendo amplamente conhecidas como Regras Mínimas das Nações Unidas para a elaboração de Medidas não Privativas de Liberdade.

Nesse contexto, vale a transcrição da apresentação firmada pelo Ministro Ricardo Lewandowski à introdução da Regras de Tóquio 4 no Brasil (2016, pág. 11), vejamos:

4 Regras de Tóquio - Regras Mínimas Padrão das Nações Unidas para a Elaboração de Medidas Não Privativas de Liberdade. Disponível em: https://www.cnj.jus.br/poder-judiciario/relacoes-internacionais/tratados/. Acesso em: 29 abr. 2020. 
Esse crescimento desenfreado da população prisional, dá-se em meio à sofisticação e o aprimoramento das formas de organização e funcionamento do aparato repressivo, notadamente sob a perspectiva de uma autorização legislativa mais punitivista.

Inspeções do Conselho Nacional de Justiça (CNJ) denunciaram, porém, que o ambiente prisional, no Brasil, ainda está marcado por outra modalidade de castigo, consistente na forma como é executado. Estruturas arquitetônicas em ruínas, celas superlotadas, úmidas e escuras e a falta de higiene qualificam, negativamente, um sistema de punições sem nenhum comprometimento com um prognóstico de não-reincidência. A superlotação desses espaços adiciona, inclusive, um componente agravante a todo esse contexto.

Enfim, o instituto da prisão, no Brasil, assim como em todo o continente sul-americano, é um assunto que reivindica uma indispensável revisitação, notadamente porque a seletividade como opera o sistema penal, majoritariamente alcançando as populações menos favorecidas, econômica e socialmente, denota o quanto tentamos encobrir, através de respostas penais, situações que demandam outra modalidade de intervenção e interferência.

Como se nota, a Regra Mínima supracitada tem como escopo estimular que os Estados-Membros desenvolvam em seus sistemas jurídicos outras opções de medidas para reduzir a utilização do encarceramento, nas quais devem ser observados os direitos humanos, as exigências da justiça social e as necessidades de reabilitação dos infratores.

Visando a conferir efetividade a esse novo modelo, surgiu a Resolução 181 do CNMP que trata, em seu artigo 18, do acordo de não persecução penal, disciplinando tratamento extrajudicial às infrações penais de médio potencial ofensivo, isto é, àquelas com pena mínima cominada inferior a 4 (quatro) anos, praticadas sem violência ou grave ameaça.

Com esse modelo, busca-se que a resolutividade das questões criminais seja antecedente à sentença penal, conferindo uma resposta estatal mais célere com medidas não privativas de liberdade, a fim de desafogar parcela do judiciário em relação a longos processos, diminuir a população carcerária em relação aos infratores com menor periculosidade e priorizar recursos financeiros e humanos aos feitos que trazem maior abalo à sociedade.

Nesse sentido, Messias (2019, pág. 3) afirma:

[...] tais demandas penais passam a representar um largo campo de atuação estratégica à disposição do Ministério Público, cuja resolu- 
tividade pode gerar uma verdadeira concentração de esforços jurídicos para o processo e julgamento dos crimes mais graves, diante da redução da hercúlea pauta de trabalho de juízes, no tocante aos fatos penais menos críticos.

Cumpre mencionar que a Resolução $\mathrm{n}^{\circ} 181$ do CNMP foi objeto de questionamento sobre sua constitucionalidade, sendo peticionadas, respectivamente, pela Associação de Magistrados Brasileiros e pelo Conselho Federal da OAB, as ADIs n 5.790/ DF e 5.793/DF.

Assim, sobre o artigo 18 do ato normativo supracitado, foi aduzido, em apertada síntese, que a Resolução criou a hipótese de acordo de não persecução penal sem aparo em lei, o que causaria grave violação aos princípios da legalidade e da segurança jurídica, mesmo havendo a previsão de homologação pelo judiciário das tratativas extrajudiciais.

Além disso, fora levantado também o argumento de que o Conselho Nacional do Ministério Público haveria inovado a ordem jurídica, extrapolando seu poder regulamentar, pois, na verdade, a pretexto de dispor sobre questão procedimental, estaria regulando matéria penal e processual penal, o que não seria possível.

Para o Conselho Federal da OAB a violação iria além, afirmando na ADI 5.793/DF 5 (2017, pág. 11):

Trata-se de regramento que viola o princípio da indisponibilidade da ação penal, previsto no art. 129, I, da Constituição Federal, que assevera a competência privativa do MP para a instauração de ação penal pública. Em se tratando de mandamento constitucional, apenas situações excepcionais podem justificar o não oferecimento da ação penal.

Defendendo a validade e a constitucionalidade do acordo de não persecução penal, é necessário compreender que o poder regulamentar não deve ficar no âmbito exclusivo do Poder Legislativo, podendo haver outras estruturas estatais aptas a elaborar ato administrativo de caráter geral, impessoal e abstrato para dar contorno às leis e à Constituição, não significando inovação da ordem jurídica.

Conforme ressalta Emerson $\operatorname{Garcia}^{6}$ (2012, pág. 3):

5 Ação Direta de Inconstitucionalidade com Pedido de Medida Cautelar-ADI 5.793/DF em face de ato normativo constante da Resolução n. 181, de 7 de agosto de 2017, editada pelo Conselho Nacional do Ministério Público -CNMP. 6 Emerson Garcia, em seu artigo "As Resoluções do Conselho Nacional do Ministério Público e o seu necessário balizamento". Revista Eletrônica do CEAF. Porto Alegre -RS. Ministério Público do Estado do RS. 
A existência do poder regulamentar está associada à concepção de que outras estruturas estatais de poder $^{7}$ podem especificar, com imperatividade, as providências a serem adotadas para o aperfeiçoamento dos comandos legais postos pelo legislador democraticamente legitimado. Trata-se de manifestação especial do princípio da legalidade, permitindo concluir que o facere estatal pode assumir contornos concretos, o ato administrativo típico, ou gerais, aqui se enquadrando o regulamento ${ }^{8}$.

Destarte, os regulamentos acabam assumindo para uma função colaborativa, interpretativa, colocando a lei à época de execução e da ordem administrativa e social contemporânea. Há necessariamente uma relação verticalizada entre o regulamento e a lei, sob pena de contradição ou usurpação de poder.

Nesse sentido, vale a transcrição do artigo 129, inciso IX, da Constituição Federal, vejamos:

Art. 129. São funções institucionais do Ministério Público: I - promover, privativamente, a ação penal pública, na forma da lei; [...] IX - exercer outras funções que lhe forem conferidas, desde que compatíveis com sua finalidade, sendo-lhe vedada a representação judicial e a consultoria jurídica de entidades públicas. (Grifo da autora).

Ademais, no mesmo diploma, o artigo 130-A, $\S 2^{\circ}$, inciso I, dispõe que:

$\S 2{ }^{\circ}$ Compete ao Conselho Nacional do Ministério Público o controle da atuação administrativa e financeira do Ministério Público e do cumprimento dos deveres funcionais de seus membros, cabendo-lhe:

I - zelar pela autonomia funcional e administrativa do Ministério Público, podendo expedir atos regulamentares, no âmbito de sua competência, ou recomendar providências; (Grifo da autora).

Como se nota, no texto supratranscrito, há uma cláusula aberta que permite ao Parquet exercer, outras atribuições, que lhe sejam conferidas, desde que em consonância com sua finalidade institucional.

7 “Se não há senão um único legislador, há uma pluralidade de detentores do poder regulamentar" (René Chapus, Droit Administratif Général, Tome 1, 15ª ed., Paris: Montchrestien, 2001, p. 649).

8 Cf. Otto Mayer, Le Droit Administratif Allemand, Tome 1er, Paris: V. Giard \& E. Brière, 1903, pp. $115 / 116$. 
Fica claro que a Resolução $n^{\circ} 181$ do CNMP extrai seu fundamento de validade diretamente da Carta Magna, assumindo caráter de ato normativo primário, isto é, de regulamento autônomo, refletindo o uso adequado da atribuição do referido órgão e preenchendo espaços que, ainda que inicialmente não alcançados pela legislação, estão em absoluta consonância finalística com esta.

Dito isto, convém afirmar que o acordo de não persecução penal é apenas mais um instrumento de atuação conferido aos presentantes ministeriais, que, no exercício da atividade de titular da ação penal pública, pode firmar tratativa de caráter político criminal, prévia ao processo penal e externa ao exercício da jurisdição, a fim de estabelecer obrigações de natureza negocial e não privativas de liberdade, promovendo um direito penal mais humanista, evitando o aumento da população carcerária.

\subsection{Acordo de não persecução penal - ANPP}

Como já foi dito, o Ministério Público, diante de seu perfil resolutivo, passou a disciplinar a matéria do acordo de não persecução penal por meio da Resolução ${ }^{\circ} 181$ do CNMP, visando a estabelecer um novo espaço que ainda não estava preenchido pela lei. Não obstante, após a sua positivação, surgiu o Projeto Anticrime e Segurança Pública, vivificado por meio da Lei $n^{\circ} 13.964$, de 24 de dezembro de 2019, que enterrou qualquer argumento sobre a ilegalidade do acordo a ser firmando entre o Parquet e o autor do fato delituoso no âmbito extrajudicial.

A Lei $n^{\circ}$ 13.964/2019 foi aprovada para aperfeiçoar a legislação penal e processual penal, trazendo a expansão legislativa da justiça consensual na seara criminal que almejava a Resolução n 181 do CNMP e as diretrizes das Regras Mínimas de Tóquio.

A referida lei acrescentou ao Código de Processo Penal - CPP o artigo 28-A, valendo a transcrição de seu caput:

Art. 28-A. Não sendo caso de arquivamento e tendo o investigado confessado formal e circunstancialmente a prática de infração penal sem violência ou grave ameaça e com pena mínima inferior a 4 (quatro) anos, o Ministério Público poderá propor acordo de não persecução penal, desde que necessário e suficiente para reprovação e prevenção do crime [...].

Nessa senda, de acordo com o CPP ${ }^{9}$ e com a Resolução n ${ }^{\circ} 181$ do CNMP, o referido

9 Código de Processo Penal, disponível em: http://www.planalto.gov.br/ccivil_03/decreto-lei/del3689compilado.htm. Acesso em: 29/04/2020. 
acordo, conceituado como instrumento extrajudicial de atuação ministerial para a não denunciação, é consolidado por meio de condições e medidas não privativas de liberdade, trazendo à tona os fundamentos da pena, isto é, a reparação do dano e a ressocialização do investigado, que, para fazer jus ao benefício, não pode ser reincidente e nem apresentar personalidade voltada à criminalidade.

\subsubsection{Natureza Jurídica do ANPP}

Quanto à natureza jurídica do acordo de não persecução penal, a doutrina se dividiu entre o viés discricionário do Ministério Público, titular da ação penal, e o direito público subjetivo do investigado ao receber a proposta.

Para uma primeira corrente, não cabe ao Parquet, ao seu livre-alvedrio, decidir se aplica ou não o ANPP. Ao contrário, o ANPP deveria seguir a mesma natureza da transação penal, que, diante do preenchimento dos requisitos legais pelo autor do fato criminoso traz um direito subjetivo ao recebimento da proposta (Messias, 2019, pág. 07).

Nesse sentido, podemos citar o julgado abaixo:

AUSÊNCIA DE OFERECIMENTO DE ACORDO DE NÃO PERSECUÇÃO PENAL AO APELADO. NULIDADE DO PROCESSO EM RAZÃO DA NÃO APLICAÇÃO DO NOVEL ARTIGO 28-A DO CÓDIGO DE PROCESSO PENAL. RETROATIVIDADE. ART. $5^{\circ}$, XL, DA CONSTITUIÇÃO DA REPÚBLICA. APLICABILIDADE. DIREITO SUBJETIVO DO RÉU. PREJUÍZO EVIDENCIADO. NULIDADE DECLARADA. [...] No caso em análise, a propositura do acordo de não persecução penal em nenhum momento foi oferecida ao acusado, mesmo após a entrada em vigor do novel diploma legal. III - Contudo, entende-se que o benefício despenalizador é um direito subjetivo do acusado, e nessas condições, a lei processual penal deve retroagir em seu benefício, nos termos do artigo $5^{\circ}$, LX, da Constituição da República, principalmente considerando-se que houve tempestiva manifestação pela defesa requerendo o benefício na primeira oportunidade que falou nos autos, não estando assim acobertado pela preclusão processual. [...] (TJ-PR - APL: 00011964220168160060 PR 000119642.2016.8.16.0060 (Acórdão), Relator: Desembargador Laertes Ferreira Gomes, Data de Julgamento: 17/07/2020, $2^{\text {a }}$ Câmara Criminal, Data de Publicação: 28/07/2020). 
Não obstante, para a segunda corrente, há um poder-dever ministerial e este teria fundamento na vagueza da redação da lei e da Resolução que afirma que o "Ministério Público poderá propor o acordo". Assim, refutando a ideia de direito subjetivo, a norma estaria estabelecendo uma faculdade ao Parquet, que, de acordo com as circunstâncias do caso concreto e diante da confissão formal do infrator, avaliaria se seria o caso ou não de firmar extrajudicialmente o benefício.

Nesse sentido, é firme e farta a jurisprudência no Tribunal de Justiça de São Paulo, valendo a transcrição de um de seus julgados:

[...] deve-se partir da premissa de que o acordo de não persecução penal deve ser resultante da convergência de vontades (acusado e MP), não podendo se afirmar, indubitavelmente, que se trata de um direito subjetivo do acusado [...]. Ademais, o legislador previu no art. 28-A, $\S 14$, que diante da negativa do Ministério Público em oferecer o referido acordo, poderia o magistrado remeter os autos ao Procurador Geral de Justiça, nos termos do art. 28 do CPP [...]. No entanto, o digno Procurador Geral de Justiça manteve a posição do Promotor de primeiro grau e insistiu na recusa de oferta do referido acordo. Logo, todas as medidas possíveis ao Poder Judiciário foram tomadas para eventual realização do referido acordo, não sendo possível exigir que o Ministério Público ofereça referido benefício, pois não se trata, conforme explanado, de direito público subjetivo do réu. (TJ-SC - HC: 50158844320208240000 TJSC 5015884-43.2020.8.24.0000, Relator: JÚLIO CÉSAR MACHADO FERREIRA DE MELO, Data de Julgamento: 14/07/2020, 3ª Câmara Criminal). (Grifo da autora).

Por ora, entendemos que este direcionamento é apresentado como majoritário, visto que a tratativa de não persecução se encontra albergada pela oportunidade e conveniência, não cabendo ao juiz, inserido numa posição de reduzida intervenção em razão do sistema acusatório, exigir que o órgão ministerial realize o ANPP.

\subsubsection{Quanto ao momento de aplicação do ANPP}

Pela finalidade da norma, o ANPP visa à não judicialização criminal, mas ao aquilatar o assunto jurídico em questão, percebemos que os doutrinadores e a jurisprudência vêm se dividindo quanto ao momento de aplicação do referido benefício, sendo que, para uma primeira posição, o limite do oferecimento do ANPP seria o recebimento da 
inicial acusatória, mas, já para a segunda posição, tal marco processual não é óbice para o acordo.

Pois bem. O legislador, nos parágrafos $3^{\mathrm{a}} \mathrm{e} 4^{\mathrm{o}}$ do $\mathrm{CPP}{ }^{10}$, faz clara referência ao termo "investigado", prevendo a necessidade de homologação pelo juiz das garantias para avaliação da voluntariedade e legalidade das tratativas.

A jurisprudência, inclusive, declina-se neste sentido, visto que aplicação do ANPP, após o oferecimento da denúncia, seria um desvirtuamento da norma, especialmente de seus pressupostos e efeitos jurídicos. Assim, vale a transcrição do julgado do Superior Tribunal de Justiça:

[...] O conteúdo do art. 28-A revela, com isso, a introdução de um negócio jurídico processual realizado na fase investigatória capaz de obstar o oferecimento de denúncia (efeito imediato de não persecução) e a potencial futura aplicação da pena cominada no tipo penal (efeito mediato despenalizante). Se uma norma jurídica traz, expressamente, um aspecto temporal que condiciona a sua aplicação, aplicá-la de modo distinto não seria dar-lhe retroatividade, mas, isso sim, criar e aplicar outra norma. O ANPP tem aplicação antes do oferecimento da denúncia; não existe fora desse momento, porquanto tal aspecto temporal compõe a respectiva norma. Entender que o artigo poderia ter incidência de modo a paralisar ação penal em curso para que, realizado acordo depois da denúncia, tenha o efeito de suspender ação penal já em grau recursal é construir uma norma completamente distinta, com antecedente e consequente normativos diversos dos estampados em lei. (STJ - AgRg no REsp: 1886717 PR 2020/0190008-5, Relator: Ministro FELIX FISCHER, Data de Julgamento: 06/10/2020, T5 - QUINTA TURMA, Data de Publicação: DJe 19/10/2020) (Grifo da autora).

Não obstante, cabe uma breve reflexão sobre a natureza da Lei no $13.964 / 2019$, que incluiu e alterou normas tanto no Código Penal quanto no Código de Processo Penal.

$\mathrm{Na}$ doutrina de Renato Brasileiro (2014, pág. 101), as normas processuais são subdivididas em normas genuinamente processuais e normas processuais materiais ou mistas. As primeiras cuidam de procedimentos, atos processuais e técnicas do processo,

$10 \mathrm{CPP}$ - "Artigo 28-A [...] $\S 3^{\circ} \mathrm{O}$ acordo de não persecução penal será formalizado por escrito e será firmado pelo membro do Ministério Público, pelo investigado e por seu defensor. $\S 4^{\circ}$ Para a homologação do acordo de não persecução penal, será realizada audiência na qual o juiz deverá verificar a sua voluntariedade, por meio da oitiva do investigado na presença do seu defensor, e sua legalidade". (Grifo da autora). 
aplicando-se a regra do tempus regit actum, prevista no artigo $2^{\circ}$ do CPP, que diz: "a lei processual penal aplicar-se-á desde logo, sem prejuízo da validade dos atos realizados sob a vigência da lei anterior".

Já as segundas - as normas mistas - são aquelas que abrigam conteúdos diversos, isto é, tanto de direito material quanto de direito processual, trazendo não só regras para a técnica do processo, mas também conteúdo ligado ao direito punitivo estatal e matéria que seja direito ou garantia constitucional do cidadão.

Ocorre que, às normas de direito material aplica-se a garantia constitucional da retroatividade da lei penal benéfica, prevista no artigo $5^{\circ}$, inciso XL, da CF. Então, se a norma prevê tanto parte processual penal quanto parte material, deve ser observada a regra da aplicação imediata sem retroatividade - artigo $2^{\circ}$ do CPP - ou deve-se observar a retroatividade da lei, nos termos do regra constitucional retrocitada, cabendo o ANPP ainda que após o oferecimento da denúncia?

A doutrina responde à indagação afirmando que, no caso de norma mista/híbrida, vai ser aplicado o mesmo critério da lei penal material, isto é, o da retroatividade da lei penal no tempo em benefício do autor da infração, nos termos do artigo $5^{\circ}$, inciso XL, da Magna Carta e artigo $2^{\circ}$ do Código Penal. Nesse sentido, vale mencionar o que diz o §13, do artigo 28-A, acrescentado pela Lei $\mathrm{n}^{\circ}$ 13.964/2019: "Cumprido integralmente o acordo de não persecução penal, o juízo competente decretará a extinção de punibilidade".

Ora, percebe-se que estamos diante de uma norma mista, que, além de versar técnica processual, versa nítida norma de direito material, visto que criou uma outra hipótese de extinção da punibilidade como resultado do integral cumprimento do ANPP.

Nessa senda, com base na interpretação sistemática da norma e nos ensinamentos da doutrina, podemos afirmar que o inteiro teor do artigo 28-A e seus parágrafos poderá alcançar fatos anteriores à vigência da lei, excepcionando a regra de aplicação do acordo apenas aos casos não denunciados, permitindo que seja formulada a proposta ainda que já recebida a inicial acusatória, desde que preenchidos os requisitos subjetivos e objetivos previstos na lei.

Agora, longe de esgotar o tema, é prudente a seguinte pontuação. Fora esclarecido que, em razão da natureza mista da Lei no $13.964 / 2019$, seria perfeitamente possível o oferecimento do ANPP para os fatos já denunciados e em fase de persecução penal em juízo. Mas, seria cabível a sua aplicação após o pronunciamento judicial condenatório, seja ele recorrível ou irrecorrível?

A equipe do Centro de Apoio Operacional Criminal do Ministério Público do Esta- 
do de São Paulo ${ }^{11}$ (2020, pág. 6), defende a ideia de não aplicação após a condenação, mesmo havendo confissão, aduzindo o seguinte:

$[\ldots]$ há que se estabelecer um limite, que deverá levar em conta a compatibilidade entre o aspecto processual do instituto e a etapa em que se encontre o processo. E, nesse ponto, não há dúvida de que o limite é a prolação da sentença condenatória.

O entendimento da $6^{\text {a }}$ Turma do Supremo Tribunal de Justiça também foi na direção supracitada, visto que a norma de natureza jurídica mista e mais benéfica ao réu deveria retroagir em seu benefício, mas desde que o processo não tenha transitado em julgado ${ }^{12}$.

Tal afirmação leva em conta, entre outros fundamentos, o valor epistemológico do instituto da confissão, que é valorada em benefício do autor do crime por questões político-criminais, em especial, por ser interpretada como um serviço à justiça penal, simplificando toda a fase de instrução probatória e conferindo ao aplicador do direito a certeza moral de uma condenação justa (CAPEZ, 2007, pág. 455).

Assim, se acusado, depois do logo caminho de instrução criminal, e após o decreto condenatório, resolve assumir a responsabilidade criminal, pode-se afirmar que já se esvaziou a finalidade do benefício confessional, isto é, não haverá mais utilidade, visto que em nada colaborou para a administração da justiça, sendo a sentença válida, refletindo perfeitamente as consequências, não devendo ser anulada a fim de permitir o eventual acordo de não persecução penal.

Por fim, vale destacar que o Supremo Tribunal Federal, no âmbito do Habeas Corpus n. ${ }^{0} 185.913 / \mathrm{DF}^{13}$, com relatoria do Ministro Gilmar Mendes, reconhecendo a repercussão geral, delimitou algumas indagações em razão dos diversos posicionamentos dos tribunais sobre a matéria, e, entre eles, encontra-se a discussão sobre a natureza da norma inserida no art. 28-A do CPP, bem como sobre o momento limite de aplicação do acordo. Aguardamos o julgamento.

11 Boletim Criminal no 04/2020 do CAO Criminal do MPSP. Disponível em: http://www.mpsp.mp.br/portal/page/portal/ Criminal/Boletim_Semanal/boletim\%20CAOCrim\%20ABRIL\%2020\%20semana\%202\%20.pdf.pdf. Acesso em: 27 abr. 2020.

12 STJ - AgRg no HC: 575395 RN 2020/0093131-0, Relator: Ministro NEFI CORDEIRO, Data de Julgamento: 08/09/2020, T6 - SEXTA TURMA, Data de Publicação: DJe 14/09/2020. Disponível em: https://stj.jusbrasil.com.br/jurisprudencia/930636258/agravo-regimental-no-habeas-corpus-agrg-no-hc-575395-rn-2020-0093131-0. Acesso em: 15 out. 2020. 13 Supremo Tribunal Federal - HC: 185913 DF 0092967-77.2020.1.00.0000, Relator: GILMAR MENDES, Data de Julgamento: 09/11/2020, Data de Publicação: 11/11/2020. Disponível em: https://stf.jusbrasil.com.br/jurisprudencia/1121882995/ habeas-corpus-hc-185913-df-0092967-7720201000000/inteiro-teor-1121882999. Acesso em: 12. nov. 2020. 


\subsubsection{O Direito ao Silêncio e o acordo de não denunciação}

Vimos, na presente pesquisa, que a aceitação, por parte o acusado, da imputação da infração penal, isto é, a confissão da autoria delitiva, firmada em termo próprio perante o Parquet, é condição imprescindível para a realização do acordo de não denunciação. Assim sendo, surge a indagação: caso o acusado tenha negado sobre os fatos em sede policial ou em juízo, poderá, ainda assim, o Ministério Público oferecer o acordo?

A doutrina tem-se apresentado, de forma unânime, no sentido de que, caso o investigado tenha refutado a infração, isto é, negando a sua autoria, não poderá ser beneficiado com o ANPP, não cabendo ao órgão ministerial insistir no pronunciamento de autoria, sob pena de descaracterizar a voluntariedade da confissão. Não obstante, nada impede que haja a retratação voluntária do agente, permitindo que este, a partir de sua confissão formal e circunstanciada dos fatos, usufrua do referido benefício.

Por outro lado, em vez da confissão ou negativa de autoria, pode ocorrer o silêncio, notadamente nos casos em que, no momento da indagação sobre os fatos, o investigado/ réu não admite e nem nega o que lhe foi imputado. Diante desta circunstância, caberia a proposta de ANPP?

É preciso ter em mente que o direito ao silêncio é inato, inerente ao acusado, devendo ser entendido no processo penal como uma proteção constitucional.

Contudo, caso o investigado ou denunciado, seja na fase policial ou em juízo, tenha exercido seu direito ao silêncio, garantia constitucional prevista no artigo $5^{\circ}$, LXIII, da $\mathrm{CF}$, a doutrina diverge sobre a possibilidade ou não de aplicar o acordo.

Para uma primeira corrente, não havendo confissão expressa, não poderá ser realizado o ANPP, devendo o silêncio ser entendido como não confissão, a fim de não permitir o início das tratativas, o que representaria o seguimento da persecução penal em juízo com o oferecimento da inicial acusatória.

Nesse sentido, advogam Marco Couto e Ana Paula Couto ${ }^{14}$, afirmando:

No dia a dia forense, verificamos que em um número expressivo de procedimentos policiais o investigado opta pelo silêncio, principalmente quando não possui advogado na fase policial. A rigor, o investigado é chamado à sede policial para prestar esclarecimento e lá comparece desacompanhado de um defensor. Se o investigado opta pelo seu direito ao silêncio, o acordo de não persecução penal fica inviável porque um dos seus requisitos é justamente a confissão do investigado.

14 Ana Paula Couto e Marco Couto. Artigo: O PACOTE ANTICRIME: O ACORDO DE NÃO PERSECUÇÃO PENAL APÓS O RECEBIMENTO DA DENÚNCIA. Disponível em: https:/emporiododireito.com.br/leitura/o-pacote-anticrimeo-acordo-de-nao-persecucao-penal-apos-o-recebimento-da-denuncia. Acessado em: 27 abr. 2020. 
Para a segunda corrente, deve-se observar o preceito do artigo 186, do Código de Processo Penal, no qual fica estabelecido que o silêncio não pode ser interpretado de forma prejudicial ao investigado/acusado, cabendo ao órgão ministerial contatar o investigado ou pugnar em juízo a notificação do réu para que seja possibilitada a confissão.

Essa trilha é a orientada pelo Ministério Público do Estado de Goiás ${ }^{15}$, aduzindo que a confissão citada no caput do art.28-A deve ser aquela manifestada voluntariamente no momento da celebração do acordo, apontando que:

[...] Essa confissão prestada ao MP durante as tratativas do acordo independe da negativa de confissão realizada no ato do interrogatório no curso da investigação preliminar ou do inquérito policial, perante a Autoridade Policial, pois, nessa fase, o investigado pode utilizar-se desse direito, conforme lhe é assegurado constitucionalmente. O silêncio do investigado, de acordo com a franquia do art.

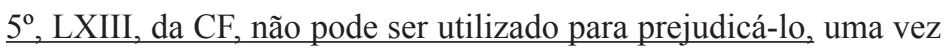
que a nova regra do CPP indica um procedimento específico, inclusive com momento adequado, para a formalização do ajuste que pressupõe a confissão. A confissão, assim, deve ser tratada como pressuposto para o ANPP, seja ela realizada perante a autoridade policial, seja perante o Ministério Público. No entanto, a ausência na fase policial não implica, por si só, a inviabilidade da proposta. (Grifo da autora).

Firmando tal entendimento, encontra-se o Enunciado $n^{\circ} 13$ da I Jornada de Direito e Processo Penal do Conselho de Justiça Federal ${ }^{16}$, que dispõe: "a inexistência de confissão do investigado antes da formação da opinio delicti do Ministério Público não pode ser interpretada como desinteresse em entabular eventual acordo de não persecução penal”.

Destarte, entendemos que a garantia constitucional de silenciar durante as investigações realmente não pode ser óbice à análise para a proposta do acordo de não persecução penal, devendo ser oportunizada, perante o Parquet, a possibilidade de confissão formal e circunstanciada dos fatos em sede policial, o que atrairia o poder-dever de análise da oferta do acordo de não persecução.

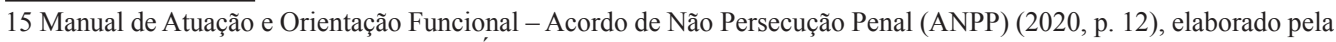
Equipe do Centro de Apoio Operacional - Área de atuação criminal do MPGO.

16 I Jornada de Direito e Processo Penal, realizada pelo Centro de Estudos Judiciários do Conselho da Justiça Federal (CEJ/CJF), de 10 a 14 de agosto de 2020, aprovou 32 enunciados. 


\subsubsection{As possíveis condições para a justiça consensual do ANPP}

A resolução $n^{\circ} 181$ do CNMP e a Lei $n^{\circ} 13.964 / 2019$ apresentaram nova roupagem à justiça consensual brasileira com o acordo de não persecução penal. Contudo, vale registrar que existem diversos modelos deste tipo de justiça, que visa ao acordo entre as partes para a solução dos conflitos.

O doutor Jamil Chaim Alves (2018, pág. 218) apresenta em sua doutrina alguns perfis de justiça consensual. Para ele, há o perfil reparador, com objetivo primordial na reparação de danos à vítima; há o perfil restaurativo, visando não só da reparação do dano, mas também a pacificação social da coletividade; há o modelo negociado, tendo por base a confissão do delito, partindo para um acordo com o órgão acusador quanto às medidas ou sanções a serem aplicadas ao acusado; e há o modelo de justiça colaborativa, que, por meio da colaboração do autor do crime, informações e provas são angariadas em troca de benefícios penais e processuais penais.

Encontramos semelhança entre o perfil negociado e o acordo de não persecução penal, sendo o acordo subordinado às seguintes condições, que podem ser aplicadas de forma cumulativa ou alternativa: a) reparar o dano ou restituir a coisa à vítima, exceto na impossibilidade de fazê-lo; b) renunciar voluntariamente a bens e direitos indicados pelo Ministério Público como instrumentos, produto ou proveito do crime; c) prestar serviço à comunidade ou a entidades públicas por período correspondente à pena mínima cominada ao delito diminuída de um a dois terços, em local a ser indicado pelo juízo da execução; d) pagar prestação pecuniária a entidade pública ou de interesse social; e e) cumprir, por prazo determinado, outra condição indicada pelo Ministério Público, desde que proporcional e compatível com a infração penal imputada.

Nota-se que a Lei n ${ }^{\circ}$ 13.964/2019 não só reproduziu alguns dispositivos, mas também trouxe novos elementos ao ordenamento jurídico para o ANPP, visando a aprimorar o sistema de tratativas e conferir segurança jurídica na justiça consensual em questão.

Independente das novidades, vale a pena destacar alguns pontos da legislação supracitada, para que o acordo seja válido e eficaz. O acordo de não denunciação exige que haja a sua homologação pelo juízo competente, a fim de que seja verificada a sua voluntariedade, por meio da oitiva do investigado na presença do seu defensor, e sua legalidade. Se o juiz considerar inadequadas, insuficientes ou abusivas as condições dispostas no acordo de não persecução penal, devolverá os autos ao Ministério Público para que seja reformulada a proposta de acordo, com concordância do investigado e seu defensor.

De outro modo, caso a tratativa seja homologada, mas descumprida sejam quaisquer das condições estipuladas, o Ministério Público deverá comunicar ao juízo, para fins de sua rescisão e posterior oferecimento de denúncia, não havendo que se falar em detração 
penal, visto que não houve pena privativa da liberdade.

Por fim, sendo cumprido de forma integral o acordo de não persecução penal, o juízo competente decretará a extinção de punibilidade do investigado outrora submetido às medidas de não encarceramento.

\title{
4 CONSIDERAÇÕES FINAIS
}

É notável que, nos últimos anos, a seara criminal de justiça consensual alcançou novos horizontes, ganhando o Ministério Público novas atribuições, notadamente podendo avaliar se as demandas mais leves podem se resolver antes da fase de judicialização.

Percebe-se que o Parquet ganha reforço na sua postura resolutiva, isto é, alcançando a resolução do problema no campo extrajudicial, especialmente, por meio do acordo de não persecução penal, instrumento este que supera as estratégias criminais tradicionais que, frequentemente, logram baixo êxito no Poder Judiciário.

Por todo o exposto, conclui-se que o ANPP está em fase inicial de aplicação, mas apresenta-se de forma adequada a uma orientação político-criminal mais humana e eficiente, especialmente, por conferir ao acusado o benefício de não sofrer uma condenação criminal, permitindo também uma resposta rápida à sociedade, mostrando a credibilidade dos órgãos públicos, bem como permite que a vítima seja reparada pela infração que sofrera de forma mais célere e eficiente.

\section{THE PUBLIC MINISTRY IN CONSENSUS JUSTICE OF THE CRIMINAL NON-PERSECUTION AGREEMENT}

\begin{abstract}
This research addresses the issue of consensual justice as an instrumental means to provide speed and efficiency to the legal system in the criminal proceedings. In this sense, an attempt is made to establish a study on the origin and purpose of the Non-Criminal Persecution Agreement - ANPP, signed between the Public Ministry and the perpetrator of the criminal offense, in order to achieve consensual justice through the application of non-liberty deprivation measures, as well as to verify the action field of the ministerial body, in view of the legislation analysis and the specific case, to make the non-denunciation.
\end{abstract}

Keywords: Consensual justice; Non-criminal prosecution agreement; Public ministry. 


\section{REFERÊNCIAS}

Ação Direta de Inconstitucionalidade com Pedido de Medida Cautelar - ADI 5.793/ DF. Disponível em: http://redir.stf.jus.br/estfvisualizadorpub/jsp/consultarprocessoeletronico/ConsultarProcessoEletronico.jsf?seqobjetoincidente=5288159. Acesso em: 29 abr. 2020.

Boletim Criminal Comentado - 04/2020. Centro de Apoio do Ministério Público do Estado de São Paulo. Disponível em: http://www.mpsp.mp.br/portal/page/portal/Criminal/Boletim_Semanal/boletim\%20CAOCrim\%20ABRIL\%2020\%20semana\%20 2\%20.pdf.pdf Acesso em: 27 abr. 2020.

BRASIL. Decreto-Lei 2.848, de 07 de dezembro de 1940. Código Penal. Disponível em: http://www.planalto.gov.br/ccivil_03/decreto-lei/del3689compilado.htm. Acesso em: 29 abr. 2020.

BRASIL. Presidência da República. Código de Processo Penal. Disponível em: http:// www.planalto.gov.br/ccivil_03/decreto-lei/del3689compilado.htm. Acesso em: 10 abr. 2020.

BRASIL. [Constituição (1988)]. Constituição da República Federativa do Brasil de 1988. Brasília, DF: Presidência da República, [2020]. Disponível em: http://www.planalto.gov.br/ccivil_03/constituicao/constituicao.htm. Acesso em: 10 abr. 2020.

BRASIL. Superior Tribunal de Justiça. Pesquisa de Jurisprudência. AgRg no HC: 575395 RN 2020/0093131-0, Relator: Ministro NEFI CORDEIRO, Data de Julgamento: 08/09/2020, T6 - SEXTA TURMA, Data de Publicação: DJe 14/09/2020. Disponível em: https://stj.jusbrasil.com.br/jurisprudencia/930636258/agravo-regimental-no-habeas-corpus-agrg-no-hc-575395-rn-2020-0093131-0. Acesso em: 14 out. 2020.

BRASIL. Supremo Tribunal de Federal. Pesquisa de Jurisprudência. HC: 185913 DF 0092967-77.2020.1.00.0000, Relator: GILMAR MENDES, Data de Julgamento: 09/11/2020, Data de Publicação: 11/11/2020. Disponível em: https://stf.jusbrasil.com.br/ jurisprudencia/1121882995/habeas-corpus-hc-185913-df-0092967-7720201000000/ inteiro-teor-1121882999. Acesso em: 12 nov. 2020.

CAPEZ, Fernando. Curso de Direito Penal: Parte Geral. 11. Ed. São Paulo: Saraiva, 2007. Vol. 1.

CENTRO DE ESTUDOS JUDICIÁRIOS DO CONSELHO DA JUSTIÇA FEDERAL (CEJ/CJF). I Jornada de Direito e Processo Penal. Disponível em: https://dizerodireitodotnet.files.wordpress.com/2020/08/enunciados-aprovados-ijdpp-vf.pdf. Acesso em: 20 nov. 2020.

COUTO, A. P.; COUTO, M. O Pacote Anticrime: O Acordo de não Persecução Penal após o recebimento da denúncia. Disponível em: https://emporiododireito.com. 
br/leitura/o-pacote-anticrime-o-acordo-de-nao-persecucao-penal-apos-o-recebimento-da-denuncia Acesso em: 27 abr. 2020.

GARCIA, Emerson. As Resoluções do Conselho Nacional do Ministério Público e o seu necessário balizamento. Revista Eletrônica do CEAF. Porto Alegre -RS. Ministério Público do Estado do RS. Vol. 1, n. 1, out. 2011/jan. 2012. Disponível em: https:// www.mprs.mp.br/media/areas/biblioteca/arquivos/revista/edicao_01/vollno1art2.pdf Acesso em: 10 abr. 2020.

LIMA, Renato Brasileiro de. Manual de processo penal. 2a Edição. Editora JusPodivm, 2014.

Manual de Atuação e Orientação Funcional - Acordo de Não Persecução Penal (ANPP) (2020, pág. 12), elaborado pela Equipe do Centro de Apoio Operacional - Área de atuação criminal do MPGO. Disponível em : http://www.mpgo.mp.br/ portal/arquivos/2020/02/14/18_08_30_417_Manual_Acordo_de_N\%C3\%A3o Persecu\%C3\%A7\%C3\%A3o_Penal.pdf Acesso em: 29 abr. 2020.

MESSIAS, Mauro. Acordo de não persecução penal - teoria e prática. Editora Lumen Juris, 2019.

Portal do STF/Processos. Arguição de Preceito Fundamental no 347. Disponível em: http://portal.stf.jus.br/processos/detalhe.asp?incidente $=4783560$ Acesso em: 04 abr. 2020.

PACHECO, Viviane. O direito ao acordo de não persecução penal. Disponível em: https://vivianepacheco.jusbrasil.com.br/artigos/816532807/o-direito-ao-acordo-de-nao-persecucao-penal-aos-condenados Acesso em: 29 abr. 2020.

Regras de Tóquio - Regras Mínimas Padrão das Nações Unidas para a Elaboração de Medidas Não Privativas de Liberdade. Disponível em: https://www.cnj.jus.br/ poder-judiciario/relacoes-internacionais/tratados/ Acesso em: 29 abr. 2020.

TÁvORA, Nestor; ROQUE, Fábio. Código de Processo Penal para Concursos. 4. ${ }^{a}$ ed. Salvado: Jus Podivm, 2013. 